\title{
Attitude Change in Older Adults Fallen for a Special Fraud
}

\author{
Eriko Musashi ${ }^{*}$, Takaaki Hosoda *
}

\begin{abstract}
Cases of special fraud in Japan have been increasing and have become one of the serious social issues in recent years. Special fraud is a general term referring to crimes that are related to obtaining money with various methods, for example, convincing a victim to transfer his/her money to unknown persons and fraudulently using a cash card via telephone or other communication methods. Many people have become victims of special fraud, although there are many organizations, financial institutions, the police departments, etc., actively warning the public and providing information about this type of crime. We examined how older adults become victims of special fraud. Therefore, in this paper, we analyzed the attitude change in victims through the use of actual examples. Then, we identified which kinds of decision-making processes can prevent older adults becoming victims of special fraud.
\end{abstract}

Keywords: attitude change, decision-making process, dual process theory, special fraud

\section{Introduction}

Cases of special fraud in Japan have been increasing in recent years. Special fraud includes crimes that deceive victims into transferring cash to an account registered to a criminal. Various methods are used; for example, a criminal pretends to be a victim's relative or a related officer and steal cash or cash cards, a criminal obtains bank information and a victim's pin number, a criminal threatens a victim for the purpose of stealing his/her cash, or a criminal fraudulently uses a victim's cash card [1]. The United States Department of Justice states that "Fraud occurs when a person or business intentionally deceives another with promises of goods, services, or financial benefits that do not exist, were never intended to be provided, or were misrepresented." [2]

One example of a special fraud is the "It's me" scam. A criminal calls a victim and says, "It's me...", and then, the victim asks, "Are you Mr. __ ?", and so on, until the criminal is able to obtain the name of the victim's son, daughter, grandson, granddaughter, etc. The criminal then pretends to be that child, grandchild, etc., and then gives the victim a different phone number, saying, "I lost my cell phone, so I'll give you my new phone number," or "I'm sick and have a bad throat". The criminals must pretend so that they can cover up any unnatural elements. Then, after some time has passed, the criminal calls the victim again and begins to tell him/her that

\footnotetext{
*Advanced Institute of Industrial Technology, Tokyo, Japan
} 
he/she needs money immediately, saying, "I'm XX," giving the name of the victim's relative; ".I made a mistake in the stock market and spent my company's money, and if I do not return XX yen today, then I will be fired." The victim believes that his/her own relative is in trouble and is tricked into transferring or sending money to the criminal [3]. Although the circumstances may vary, special fraud has two common characteristics. First, the criminal impersonates someone close to the victim, a police officer, or an employee of a banking association. Second, the criminal tells the victim that there is an emergency.

Many financial institutions, including the National Police Agency and the Japanese Bankers Association, as well as various financial institutions, have set up special webpages with descriptions of cases and countermeasures. In addition, the automatic teller machines (ATMs) installed in financial institutions and convenience stores have posters to alert customers to special fraud, and warning screens are displayed while ATMs are operating.

As described above, many related organizations are working together on a daily basis to take countermeasures to address special fraud. Although victims receive information on special fraud on a daily basis, they are still involved in crimes, and the number of victims of special fraud has not decreased. In 2019, the number of special fraud cases was 16,836, and the monetary damage was 30.15 billion yen. Since 2010, the number of special fraud cases and the amount of financial damage have remained flat, making financial damage countermeasures an important issue.

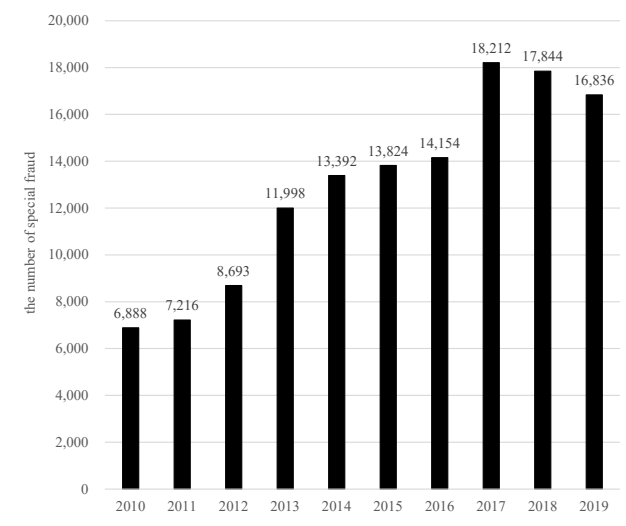

Fig 1: Yearly change in the number of special fraud[2]

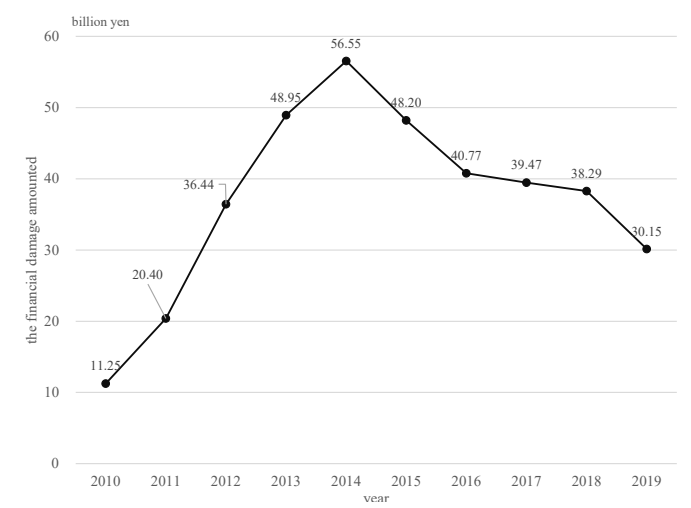

Fig 2: Yearly change in the amount of financial damage[2]

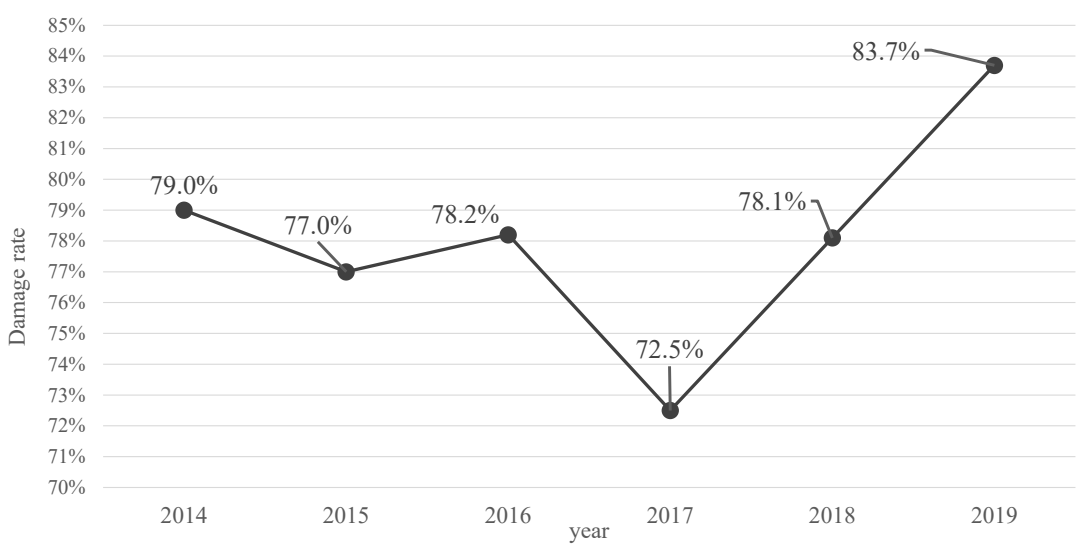

Fig. 3: Yearly change in special fraud involving older adults [2] 
Cases involving older adults and the damages they have suffered has shot up to $83.7 \%$ of total cases, which is extremely high. Figure 3 shows the official records of the secular change in special fraud cases involving older adults [4].

Why are older adults deceived by special fraud? In the field of psychology, changes in attitude due to external factors are called "attitude changes". One of the theories that explains human attitude change is a model based on dual process theory. Dual process theory is a theory that assumes that two types of information processing systems work in humans. In general, information processing systems that processes intuitively and deliberately are called Systems 1 and 2 [5].

According to Petty and Cacioppo's model, the elaboration likelihood model (ELM), and Chaiken's heuristic-systematic model (HSM), if motivation is present and cognitive processing capacity is sufficient, then intentional information processing is assumed to be taking place. Conversely, if this is not the case, then it is assumed that intuitive information processing is occurring.

In this paper, we analyze the reasons for fraud actions with these two models by examining the motives and actions involved in actual special fraud cases. In addition, we examine how special fraud can be prevented using models of attitude change.

Many studies have been conducted in various research fields on the means of special fraud. However, few analyses have focused on attitude changes in victims. In this paper, we focus on the change in victims' attitudes using two models and examine the causes of damage in special fraud cases. This will be a new and effective research stream to protect older adults from becoming victims of special fraud.

\section{Types of Special Fraud}

Special fraud have been classified into 10 categories by the Metropolitan Police Department in FY2020 to clarify their contents, since there are various methods and their criminal techniques have been diversified [1]. The details of each scam are shown in the table 1 below.

Table 1: The details of special fraud

\begin{tabular}{|l|l|}
\hline \multicolumn{1}{|c|}{ Subject } & \multicolumn{1}{c|}{ Overview } \\
\hline $\begin{array}{l}\text { "It's me" } \\
\text { scam }\end{array}$ & $\begin{array}{l}\text { This is a scam in which the criminals claim to be relatives and steal cash } \\
\text { from the victim. For example, the criminals may say, "I left my bag. I } \\
\text { found a check. I need money." then the criminals try to deceive them. }\end{array}$ \\
\hline $\begin{array}{l}\text { deposit and } \\
\text { savings scam }\end{array}$ & $\begin{array}{l}\text { For example, the criminals may say, "Your account is being used for a } \\
\text { crime. In some cases, the criminals pretend to be government officials } \\
\text { and say, "You have overpaid your medical bills. We'll take care of it for } \\
\text { you, so let's go get your card." In these ways, the criminals try to deceive } \\
\text { them. }\end{array}$ \\
\hline $\begin{array}{l}\text { Fictitious } \\
\text { billing scam }\end{array}$ & $\begin{array}{l}\text { This is a scam in which the criminals inform the victim via e-mail or } \\
\text { postcard about a pay site or consumption fees, etc., in order to cheat } \\
\text { them out of money, etc. For example, the victim is notified that "You } \\
\text { have unpaid bills. If you do not pay by the end of the day, you will be } \\
\text { taken to court" and so on. }\end{array}$ \\
\hline
\end{tabular}




\begin{tabular}{|l|l|}
\hline $\begin{array}{l}\text { Cash card } \\
\text { theft }\end{array}$ & $\begin{array}{l}\text { This is a scam in which the criminals claim to be police officers, bankers' } \\
\text { associations, or employees of major department stores and steal cash } \\
\text { cards while they are distracted. For example, the criminals may say, } \\
\text { "Your cash card is being used fraudulently, so I'm going to make it unus- } \\
\text { able." }\end{array}$ \\
\hline Refund scam & $\begin{array}{l}\text { This is a scam in which the criminals ask the victim to operate an ATM } \\
\text { to transfer money from the victim's account to their account, saying, } \\
\text { "Please complete the procedures for a refund of medical expenses, taxes, } \\
\text { insurance premiums, etc. }\end{array}$ \\
\hline $\begin{array}{l}\text { advance-fee } \\
\text { loan scam }\end{array}$ & $\begin{array}{l}\text { This is a scam in which the criminals deceive victims into believing that } \\
\text { they can easily obtain a loan when they do not actually provide the loan, } \\
\text { and then cheat them out of their money by saying, "You need a deposit. }\end{array}$ \\
\hline $\begin{array}{l}\text { securities } \\
\text { fraud }\end{array}$ & $\begin{array}{l}\text { This is a scam in which the criminals give the victim false information } \\
\text { about unlisted stocks, expensive goods, etc., which have no value at all, } \\
\text { make them believe that they will make a profit if they purchase them, } \\
\text { and then cheat their money. }\end{array}$ \\
\hline $\begin{array}{l}\text { Gambling } \\
\text { scam. }\end{array}$ & $\begin{array}{l}\text { This is a scam in which the criminals make people pay a registration fee } \\
\text { or information fee to register as a member of a group that is involved in } \\
\text { gambling (e.g., " Recruiting pachinko players") and then extort money } \\
\text { from them. }\end{array}$ \\
\hline $\begin{array}{l}\text { Sexual rela- } \\
\text { tionship } \\
\text { agency scam }\end{array}$ & $\begin{array}{l}\text { This is a scam in which the criminals posts a notice in a magazine or } \\
\text { sends an email to a person who has requested an introduction to a } \\
\text { woman and then tries to scam them out of money as a registration fee or } \\
\text { deposit. }\end{array}$ \\
\hline $\begin{array}{l}\text { Other special } \\
\text { fraud }\end{array}$ & \begin{tabular}{l} 
This refers to special frauds that do not fall under any of the above types. \\
\hline
\end{tabular} \\
\hline
\end{tabular}

These scams can be categorized into three types based on the characteristics of human behavior: the method of inciting anxiety, the method of inciting expectation, and the method of inciting speculation.

The method of inciting anxiety refers to the method of putting the victim into a state of anxiety by giving him/her a stimulus that makes him/her afraid and encourages the criminals to perform the intended act.

The method of inciting a sense of expectation refers to the method of giving the victim a sense of expectation or a feeling of foreboding to catch the victim off guard, and then encouraging the criminals to perform the intended act by targeting the victim's diminished attention span.

The method of inciting speculation refers to the method of encouraging the criminal's intentional act by giving the victim a sense of elation that he or she can gain a large profit without labor through good fortune or coincidence, catching the victim off guard, and targeting the victim's reduced attention span. It is a method that can lead to greater carelessness because it gives a greater sense or premonition than the sense of expectation, but at the same time, it is a method that is often avoided because it lacks a sense of reality.

The following table shows an analysis of the actual situation in terms of the percentage of damage, success rate, and amount of damage based on these three methods that are derived from behavioral characteristics. This content has been analyzed based on the data of the damage situation at Tokyo in 2020 [6]. 
Table 2: The situation of damage caused by special fraud at Tokyo in FY2020

\begin{tabular}{|c|c|c|c|c|c|c|}
\hline $\begin{array}{c}\text { The characteristics of } \\
\text { human behavior }\end{array}$ & Subject & $\begin{array}{c}\text { Recognition } \\
\text { rate }\end{array}$ & $\begin{array}{l}\text { Success } \\
\text { rate }\end{array}$ & Total damage & $\begin{array}{c}\text { Total } \\
\text { damage rate }\end{array}$ & $\begin{array}{c}\text { Damage amount } \\
\text { per case }\end{array}$ \\
\hline \multirow{4}{*}{$\begin{array}{l}\text { The method of } \\
\text { inciting anxiety }\end{array}$} & "It's me" scam & $19.5 \%$ & $90.6 \%$ & $¥ 1,930,937,685$ & $90.6 \%$ & $¥ 3,764,011$ \\
\hline & $\begin{array}{l}\text { deposit and savings } \\
\text { scam }\end{array}$ & $23.4 \%$ & $96.5 \%$ & $¥ 1,185,361,444$ & $96.5 \%$ & $¥ 1,812,479$ \\
\hline & Fictitious billing scam & $5.5 \%$ & $99.4 \%$ & $¥ 573,477,444$ & $99.4 \%$ & $¥ 3,629,604$ \\
\hline & Cash card theft & $25.6 \%$ & $98.8 \%$ & $¥ 1,307,278,692$ & $98.8 \%$ & $¥ 1,788,343$ \\
\hline \multirow{2}{*}{$\begin{array}{l}\text { The method of } \\
\text { inciting expectation }\end{array}$} & Refund scam & $24.2 \%$ & $100.0 \%$ & $¥ 1,184,719,809$ & $100.0 \%$ & $¥ 1,692,457$ \\
\hline & advance-fee loan scam & $0.9 \%$ & $100.0 \%$ & $¥ 50,765,434$ & $100.0 \%$ & $¥ 2,030,617$ \\
\hline \multirow{3}{*}{$\begin{array}{l}\text { The method of } \\
\text { inciting speculation }\end{array}$} & securities scam & $0.6 \%$ & $81.3 \%$ & $¥ 74,787,679$ & $81.3 \%$ & $¥ 5,752,898$ \\
\hline & Gambling scam & $0.3 \%$ & $100.0 \%$ & $¥ 30,969,726$ & $100.0 \%$ & $¥ 3,096,973$ \\
\hline & $\begin{array}{l}\text { Sexual relationship } \\
\text { agency scam }\end{array}$ & $0.1 \%$ & $100.0 \%$ & $¥ 2,810,000$ & $100.0 \%$ & $¥ 1,405,000$ \\
\hline
\end{tabular}

It can be said that most of the special frauds are committed by the method of inciting anxiety, because the method of inciting anxiety accounts for about $74 \%$ of the damage ratio and about $79 \%$ of the damage amount. The method of inciting a sense of expectation is a clever use of the psychology of the victim who expects to receive money back as a refund, which means that inciting a sense of expectation is also highly effective. On the other hand, although the number of cases of inciting speculation is limited, the amount of damage per case is the largest among all the types of frauds, so it can be considered that reducing the victim's attention by inciting speculation is also as effective as or more effective than the sense of expectation.

As described above, each type of special fraud can be organized based on the characteristics of human behavior. In order to further analyze the characteristics of human behavior, the concept of attitude change, which is used in behavioral and social psychology, will be introduced to analyze cases of special fraud.

\section{Two Models of Attitude Change}

Attitude change refers to "a change in the attitude of the receiver toward a certain problem (theme)." It is a term often used in behavioral and social psychology. As one theory for explaining attitude change, two representative models from dual process theory have been described [7].

\section{A. Elaboration Likelihood Model}

One representative model that explains human attitude change is Petty and Cacioppo's ELM [8]. According to the ELM, human processing via the central route functions when the receiver considers the message important or has sufficient cognitive processing capacity, such as time and mental margin, to process the message. On the other hand, if the receiver's motivation to process the message or cognitive processing ability is insufficient, or if both are missing for the receiver, then the message will be processed via the peripheral route. 
In ELM processing, humans use the central route to examine a situation when they receive an important message related to their family or other people with whom they are close. What is important, here, is that they have the ability to process the message based on certain motivations, grounds and reasons. Moreover, when humans receive unimportant or unworthy messages, they process them through the peripheral route but are unable to process them with reason.

Petty and Cacioppo conducted an experiment on university students to see they would agree or disagree to implement an examination to graduate from university. In this experiment, three factors, the recipient's self-involvement, the quality of the rationale, and the number of rationales, were controlled. Two different consequences were identified. First, students were able to agree based on logical and quality analysis and were not affected by the number of arguments when their own self-involvement was high. The second finding showed that the students were being influenced by a number of arguments rather than using logical and quality arguments when they had less recipient self-involvement. Based on this experiment, Petty summarized that humans tend to process less information via the peripheral route than via the central route [9].

Furthermore, it has been mentioned that the attitudes determined by the central route are more likely to persist compared to those determined by the peripheral route. the attitude determined by the peripheral routes is likely to change. If there are factors that toned to be reconsidered, then the information determined by the central route will be reprocessed. The flowchart in Figure 4 shows the ELM recognition process described above [3].

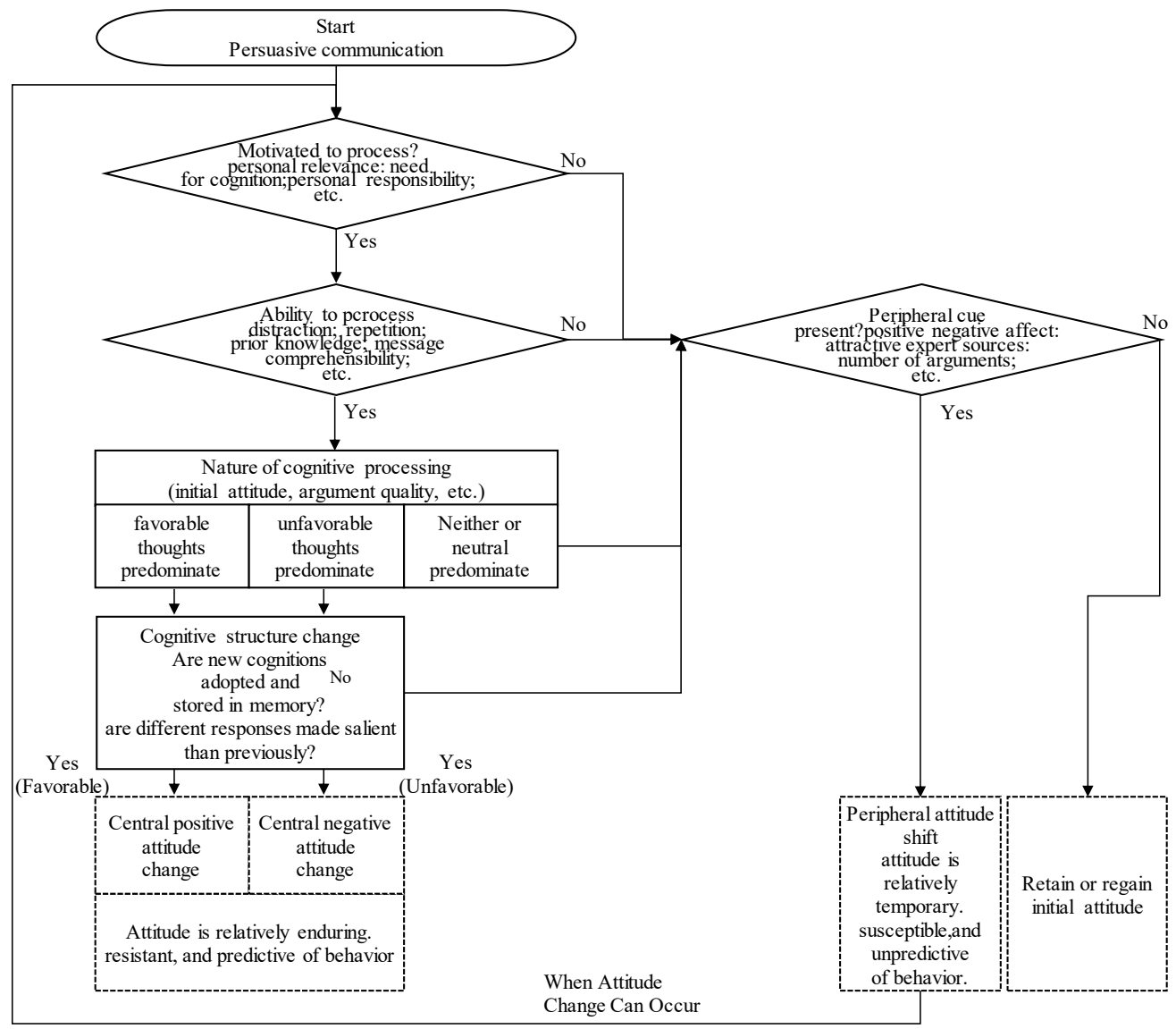

Fig. 4: ELM Flowchart (Created by the authors based [6]) 


\section{B. Heuristic-Systematic Model}

At the same time as the ELM was proposed, a heuristic-systematic model, called HSM, was also proposed [8]. Similar to the ELM, the HSM considers the processing of persuasion messages in two parts: in the HSM, the processing that corresponds to System 1 is called heuristic processing, and the processing that corresponds to System 2 is called systematic processing. In the HSM, humans are motivated to obtain the right conclusions with the right attitudes, and the model judges whether a persuasion message is correct. If the receiver finds the persuasion message to be interesting and has the necessary cognitive processing ability, then systematic processing begins. If either of the above requirements is lacking, then heuristic processing is performed. Heuristic processing is carried out with limited information compared to systematic processing. Chaiken stated that in heuristic processing, the receiver of a persuasion message does not process the details of the message using systematic processing but rather uses heuristic processing based on his/her experience to reduce the burden of cognitive processing. The receiver judges the validity of the message using simple rules such as "experts are right," "reliable people have honest opinions," "many people agree," and "long persuasion messages are informative and correct" [10].

Chaiken conducted an experiment to determine how the self-involvement level and favorable impression of a speaker affect receivers' decision-making process, and the experiment was performed by controlling for these two factors. Recipients consider the content of persuasion messages carefully to decide whether to change their attitudes, when self-involvement was high. On the other hands, they could decide whether they needed self-involvement to change their attitudes when self-involvement was low [10].

If information is processed using only heuristic processing, on the one hand, then it is likely that attitudes will change when an objection message is received, similar to processing in the ELM. Systematic processing, on the other hand, is a method that processes a large amount of information. In systematic processing, the content of persuasion messages is carefully examined to reach a conclusion. The flowchart of the HSM recognition process described above is shown in Figure 5 [3].

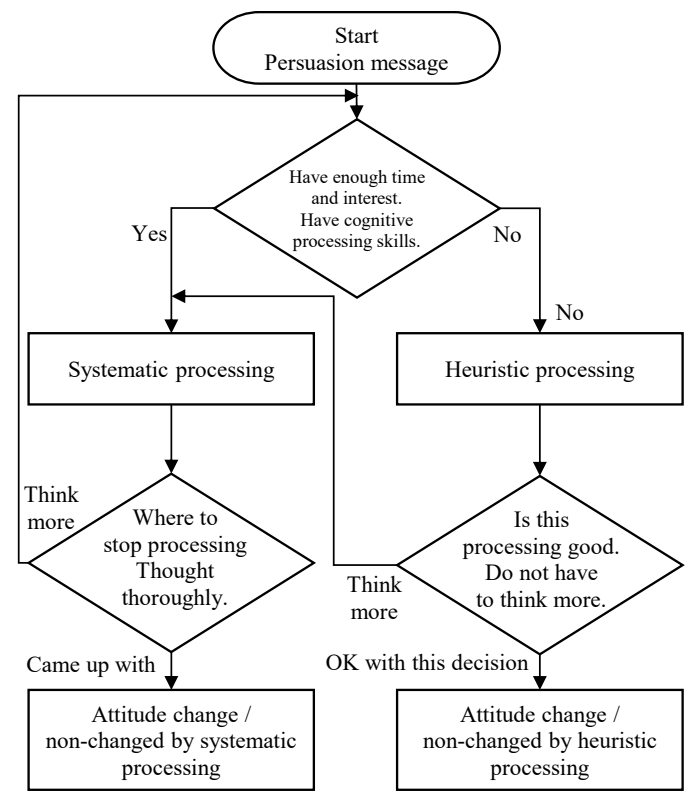

Fig. 5: HSM Flowchart (Created by the authors based [8]) 


\section{Cases of Attitude Change Due to Special Fraud}

In this section, we explain how victims of special fraud perform cognitive processing when they receive a fraud message and how they transfer money based on actual cases.

[Case 1: a woman in her 50s] First, she received a call from someone pretending to be her son. The criminal said that he had lost his cell phone and had changed his phone number. At that time, she felt that his voice was different from that of her son, so she asked him, "What is the matter?" The criminal then told her, "This is not an 'it's me scam." She thought that if the man on the phone were a criminal, then he would not mention anything about 'it's me, it's not a scam'. She believed the criminal's words and changed her son's phone number registration to the number the criminal had mentioned. The next day, she received a call from the criminal, who told her, "I had borrowed money to buy stocks.". In addition, he told her that if she did not lend him the money today, then he would have to give someone an I.O.U. Then, she thought, "Maybe a gang is involved," and "I can't let them ruin my son's life." Therefore, she transferred 980,000 yen from her bank to the criminal [11].

[Case 2: a woman in her 60s] The criminal, who claimed to be a Bankers Association employee, called the woman and said, "We will freeze your account because it is at risk" and "Your account has been used for special fraud and the victim's money has been transferred." She was worried that her account was being misused. The criminal cleverly obtained her account number and PIN. Then, the criminal said, "A staff member of the Bankers Association will visit you later."

After a while the criminal came to her house and said, "This card cannot be used, so I will keep it temporarily." Finally, he cheated the cash card and withdrew 500,000 yen [11].

[Case 3: a woman in her 80s] She received a phone call from a person she thought was her son. He said to her, "There was an incident at work, and I borrowed some money from my boss. I want you to repay the money instead." Later, she received a call from a man claiming to be her son's boss. He said, "I think your son told you about this, but I need you to repay one million yen. I am in trouble because of the new coronavirus, and your son is also in trouble. I want you to pay it back immediately." She prepared approximately one million yen in cash as instructed. She was going to give it to him when he came to her home, but then she received another call from her son's boss. He said, "I could not come to you because of an urgent matter. I will send one of my men instead, and I would like you to give it to him at another location instead of at your home." She said, "I would like to give it to him in person if possible," but the criminal refused. She went to the designated place and handed the cash to the young man, though she was suspicious. Later, the man pretending to be her son's boss called her and said, "I did receive about one million yen. I will deliver the receipt this evening." However, he never showed up [11].

[Case 4: a man in his 70s] A man offered to buy a POSA card for 34,000 yen at a store. When a suspicious employee asked about the situation, he said, "I was instructed to pay my computer repair costs with electronic money because my computer was infected with a virus and had been repaired remotely." The employee determined that there was a high possibility of fraud and reported it to the store manager, who then persuaded the man to consult the police first, showing him the fraud prevention information that had been distributed by the police.

Then, the police found it to be a case of fraud and were able to prevent it [12].

[Case 5: a woman in her 80s] She received a phone call from someone pretending to be her son, who said, "I got an acquaintance pregnant, and I need to pay her." She believed that the call was 
from her son. She tried to transfer 4 million yen to the criminal. In doing so, she was asked at the bank counter about the purpose of the money transfer and her relationship with the recipient. However, the criminal had told her in advance that if the teller asked her the reason for the money transfer, then she should say, "This is for the payment of my car." The bank teller thought it was unnatural for her to pay for the car, so he checked again. However, when she received a reminder call from the criminal while in the bank, she became impatient and said, "I just want you to transfer the money as soon as possible." She seemed to be completely convinced that the caller was her son. Therefore, the bank teller consulted with his supervisor and took her to another teller. He listened to her story in more detail and tried to repeatedly dissuade her from transferring the money. Since he was sure that it was a special fraud case, he reported it to the police. His persuasion did not change her intention to send the money, but the explanation from the police officer who came to the scene calmed her down. The woman finally understood that it was a special fraud case and refused to send the money [11].

[Case 6: a woman in her 80s] The victim received a phone call from a man claiming to be an employee of a securities firm, asking her to contact him when the envelope arrived. The next day, she received a pamphlet soliciting a time deposit with the name of another company written on it. Later, she received a phone call from an employee of the company mentioned in the pamphlet, who said, "You can make $45 \%$ profit per year," and was contacted several times by men pretending to be employees of other securities companies and banks. She gradually became interested in the deposit and sent the cash by letter pack [13].

\section{Consideration of Attitude Change in Light of the Example Cases}

\subsection{Analysis}

From the above section, it can be assumed that the victims of fraud are in a situation where they do not have sufficient cognitive processing capacity and that their information processing is intuitive. As a result, the behavioral examples suggest that these victims tend to be incapable of intentional information processing. The reasoning for such behavior will be analyzed and discussed based on the two models of attitude change described above.

In Case 1, the victim received a persuasion message over the phone from a criminal asking her to transfer money. At that time, the criminal also provided the victim with information, such as "I had borrowed money to buy stocks." The criminal deprived the victim of the ability and time to process the messages. As a result, the victim transferred the cash. Thus, it can be said that the victim's cognitive processing ability became inadequate due to her not being given enough time. The victim then changed her attitude through the peripheral route and heuristic processing in other words system 1 processing.

Regarding Case 2, a criminal who pretended to be an employee of a banking association said, "We will freeze your account because it is at risk" and "Your account has been used for special fraud, and your money has been transferred." Then, the victim became worried that her account was being misused. As a result, it can be assumed that the victim's attitude changed as a result of the peripheral route or heuristic processing, in short System 1 processing. 
To clarify this, Chaiken experimented with a receiver's self-involvement in the persuasion theme and a sender's favorable perception. The results showed that in the case of low self-involvement (heuristic processing), the number of persuasion messages was not much affected, and the victim agreed to transferring money to the sender according to her trust in and favorable feelings toward the sender [8]. In this case, too, the victim believed that the message was from a trusted financial institution, and as a result, she handed over her cash card, and the deposit was withdrawn. Chaiken's experimental results are a good illustration of the results in this case (Case 2).

With the spread of the new coronavirus infection, people have entered a state of anxiety and lack of mental capacity. In this situation, such as in Case 3, the criminal pretended to be the victim's son and told her, "There was an incident at work, and I borrowed some money from my boss. I want you to repay the money instead." This caused the victim to lose time and cognitive processing ability in a situation where she was mentally unavailable. As a result, the victim handed over the cash to the criminal. Victims of special fraud may change their attitudes due to System1 processing (e.g., the peripheral route and heuristic processing).

Regarding Case 4, the criminal lied to the victim that his computer was infected with a virus and that he had it repaired remotely. The victim was anxious and mentally uncomfortable. As a result, the victim processed the message from the criminal using System 1 processing (e.g., the peripheral route and heuristic processing). However, through System 2 processing (e.g., the central route or systematic processing), the victim reconsidered after an employee of the convenience store explained and showed the man credible information concerning fraud prevention awareness. Ultimately, the man was able to avoid becoming a victim of special fraud.

In Case 5, the criminal pretended to be the victim's son, saying, "I got an acquaintance pregnant, and I need to pay her." As a result, the victim lost her mental capacity. In addition, the victim lost time when the criminal made a follow up reminder call. In this way, the victim's cognitive processing ability was lost. As a result, it can be considered that the victim changed her attitude through the peripheral route and heuristic processing. However, the banker contacted the police, and the victim was subsequently persuaded by the police officer, who kept the victim calm and stopped the money transfer. In this situation, the victim was in a state where she had changed her attitude through the peripheral route and heuristic processing, in other words System1 processing, once the criminal called her. However, the "persuasion of the police officer" prompted her to reconsider.

Case 6 is a scam related to the investment of financial products that are claimed to offer large profits. By inciting the victim's speculative spirit, the criminal deceives him/her into believing in the consciousness of making money. The information is processed only by System 1 (peripheral routes and heuristic processing) because of the incentive of speculation. Furthermore, by blindly believing that they can make money, they lose their mental space and are unable to redirect their cognitive processing to the central route or systematic processing, which is the processing of System 2.

From the analysis of the above six cases, it can be understood that the victims lost their cognitive processing ability due to the messages from criminals and, then, were triggered to change their attitude via the peripheral route and heuristic processing. In the next section, why older adults change their attitudes through System1 processing (e.g., the peripheral route and heuristic processing) is clarified in two ways. 
Table 3 summarizes the above cases in terms of psychological types and characteristics of cognitive processing.

Table 3: Summary from the viewpoint of psychological type and characteristics of cognitive processing

\begin{tabular}{|c|c|c|c|}
\hline $\begin{array}{l}\text { The characteristics } \\
\text { of human behavior }\end{array}$ & case & Victim's cognitive processing & Causes of cognitive processing \\
\hline \multirow{5}{*}{$\begin{array}{l}\text { The method of } \\
\text { inciting anxiety }\end{array}$} & 1 & System1 processing & Loss of temporal leeway \\
\hline & 2 & Systeml processing & Loss of mental leeway \\
\hline & 3 & System1 processing & $\begin{array}{l}\text { Loss of temporal leeway } \\
\text { Loss of mental leeway }\end{array}$ \\
\hline & 4 & $\begin{array}{l}\text { change from System1 processing to } \\
\text { System } 2 \text { processing }\end{array}$ & Persuasion from the authoritative \\
\hline & 5 & $\begin{array}{l}\text { change from System } 1 \text { processing to } \\
\text { System } 2 \text { processing }\end{array}$ & Persuasion from the authoritative \\
\hline $\begin{array}{l}\text { The method of } \\
\text { inciting speculation }\end{array}$ & 6 & System1 processing & Loss of mental leeway \\
\hline
\end{tabular}

\subsection{Discussion on Attitude Change in Older Adults}

From the analysis of the cases in the previous section, it is clear that older adults unintentionally change their attitudes by losing their cognitive processing ability due to messages from criminals aiming to commit special fraud.

One of the that older adults change their attitudes is due to the fact that persuasion messages from criminals have the characteristic of making older adults prone to attitude change. In the example cases, criminals often misrepresent themselves as victims' relatives, and it can be said that persuasion messages from such criminals have a high degree of self-involvement for the victim. Therefore, it is highly possible that the information will be processed by the central route or systematic processing. Moreover, the criminal pretends to be a credible person, like the victim's relatives, and informs the victim that he/she (the criminal) is in serious trouble. In addition, the criminal imposes time constraints on older adults' victim, reducing his/her cognitive processing capacity. As a result, the victim is guided to process via the peripheral route or heuristic processing. shao et al. extracted the possible factors affecting elderly fraud victimization through a review of many previous studies. There are five factors: overly trusting nature, psychological vulnerability, social isolation, risk taking, and basic knowledge/informational literacy [14]. The loss of cognitive processing ability can be considered as psychological vulnerability, which is one of the factors of special fraud as described by Shao et al.

In addition, Carstensen et al. argue that older adults may feel even negative emotions as positive emotions in certain contexts. This suggests a feature of cognitive processing in System 1 that even in some negative incidents or accidents, people have a positive feeling of wanting to help their relatives or close people [15].

The second reason that older adults change their attitudes is related to the characteristics of older adults' cognitive processing. In a study on the decision making of older adults, it was found that they process less information than do younger generations, lack flexibility in learning, change their selection and spend more time processing information. Moreover, they tend to choose 
selection methods that require less cognitive ability. Additionally, they are very cautious and spend more time in judging less information than do younger generations. However, older adults could still obtain the same judgment as that of the younger generation[16]. Burton stated that through questionnaires, about $60 \%$ of the subjects were well educated about investments, and similarly, $60 \%$ of the subjects were concerned about becoming a victim of investment fraud [17]. Nevertheless, Sauer and Pak as well as Pak and Shadel confirmed that victims of investment scams are more financially literate than non-victims, and that relatively older people who are also college educated are more likely to be victims [18][19]. This is also a good indication of the characteristics of the older adults. This is also a good indication of the characteristics of the older adults.

From this study, we can conclude that older adults tend to process messages from criminals via the peripheral route or heuristic processing because they tend to process less information and choose selection methods that require less cognitive ability.

However, we can observe that some older adults could avoid being victims when trusted third parties provided them with persuasive and trustworthy information, as can be seen in two of the cases. In Cases 4 and 5, the victims were able to be calmed down by trusted third parties. As a result, they reconsidered the central route or systematic process rather than the attitude change via the peripheral route or heuristic processing.

Schoepfer and Piquero found that involvement in risky behaviors and age were important predictors of fraud victimization, as previously mentioned in research. In addition, they found that the factors affecting fraud victimization differed according to the type of crime [20]. Since we are not currently conducting research from this analytical perspective, we would like to make it our future work to conduct research in addition to the analysis of attitude change.

We can say that older adults can use System 2 processing and can avoid attitude change related to special fraud if trusted third parties provide trustworthy information to them. If this approach is successful, then it is possible to protect older adults from becoming victims of special fraud.

\section{Conclusions and Future Tasks}

In this paper, we analyzed why older adults become victims of special fraud by referring to their behavior when they encounter special fraud and identified two reasons. First, the cognitive processing of older adults is inclined toward heuristic processing. Second, criminals manipulate older adults with manipulative messages to use the peripheral route and heuristic processing, which accelerate them toward changing their attitudes.

To the best of our knowledge, this study is the first to determine the cause of becoming a victim of special fraud based on the attitude change models. We also found that based on the processing methods of attitude change models, attitude change is unlikely to be affected by special fraud if trusted third parties provide trustworthy information.

We will take this a step further to evaluate how we should approach helping older adults reconsider via the central route or systematic processing, and we will develop attitude change models of special fraud. 


\section{References}

[1] National Police Agency, "What is special fraud," Aug 2021; www.keishicho.metro.tokyo.jp/kurashi/tokushu/furikome/furikome.html.

[2] The United States Department of Justice, "Financial Fraud Crimes," Aug 2021; www.justice.gov/usao-ak/financial-fraud-crimes.

[3] Eriko Musashi, Takaaki Hosoda, "Attitude Change in Human Decision Making Process Based on Observations of victims of Special Fraud", International Conference on Decision Science, Theory and Management (DSTM 2020), 2020.

[4] Nobuo Komiya, TAugmented version: Theory and practice of crime-resistant community development, Imagine Publishing Co., Ltd. 2015, p. 87.

[5] National Police Agency, "About special fraud recognition, arrest situation, etc.," Jan 2021; www.npa.go.jp/publications/statistics/sousa/sagi.html.

[6] Metropolitan Police Department, "The situation of special fraud in 2020," Aug 2021; https://action.digipolice.jp/files/67dd7888399f322ba6637eb7706cba1a.pdf.

[7] Mitsuru Kaneko, “Theme Book Review (89) Dual Process Theory,” Marketing Journal, Marketing Society of Japan, vol. 33, no. 3, 2014, pp. 165-166.

[8] Petty, R. E., \& Cacioppo, J. T. "The elaboration likelihood model of persuasion," in L. Berkowitz (Ed.), Advances in experimental social psychology vol. 19, San Die-go,1986, pp. 123205 .

[9] Yoshiaki Imai, The Psychology of Trust and Persuasion: How Humans Affect Others, SAIENSUSHA Co., Ltd, 2006, p. 199.202.

[10] Eagly, A. H., \&Chaiken, S., "The psychology of attitudes,”, Orlando, FL, US: Harcourt Brace Jovanovich College Publishers, 1993.

[11] Japan Post Bank, Ltd, “Criminal cases such as special fraud,” Jan 2021; www.jpbank.japanpost.jp/crime/pdf/inf_crm_pdf_jirei1.pdf.

[12] Japan Franchise Association, "Measures to prevent damage from special fraud," Jan. 2021; ss.jfa-fc.or.jp/article/article_1352.html.

[13] Kanto Local Finance Bureau, "Cases of damage caused by malicious special fraud that occurred in Nagano Prefecture,” Aug 2021; http://kantou.mof.go.jp/content/000227611.pdf.

[14] Shao, J., Zhang, Q., Ren, Y., Li, X., and Lin, T., "Why are older adults victims of fraud? Current knowledge and prospects regarding older adults' vulnerability to fraud." Journal of Elder Abuse \& Neglect, vol.31, no.3, 2019, pp. 230-233.

[15] Carstensen, L. L., Fung, H. H., \& Charles, S. T.., "Socioemotional selectivity theory and the regulation of emotion in the second half of life." Motivation and Emotion, 27(2), 2003, pp.111-112. 
[16] Shinichi Satou, Well-understood elderly psychology, Minerva Shobo. 2016, p. 81.

[17] AARP Research, Washington Burton, C. "Consumer Fraud: A 2008 Survey of AARP Colorado Members' Experiences and Opinions.” Aug 2021; https://assets.aarp.org/rgcenter/consume/co_fraud_08.pdf.

[18] AARP Research, Washington Sauer, J. H., and Pak, K., "Stolen Futures: An AARP Washington Survey of Investors and Victims of Investment Fraud." Aug 2021; https://asets.aarp.org/rgcenter/consume/wa_fraud_07.pdf.

[19] AARP Research, Washington Pak, K., and Shadel, D., "AARP Foundation National Fraud Victim Study." Aug 2021; https://assets.aarp.org/rgcenter/general/fraud-victims11.pdf.

[20] Schoepfer, A., and Piquero, N. L., "Studying the correlates of fraud victimization and reporting.," Journal of Criminal Justice, vol.37, Issue2, March-April 2009, pp.209-215. 